\title{
Benefits and Harms of Screening Mammography by Comorbidity and Age: A Qualitative Synthesis of Observational Studies and Decision Analyses
}

\author{
Dejana Braithwaite, $P h D^{7}$, Louise C. Walter, MD², Monika Izano, MSc ${ }^{1,3}$, and Karla Kerlikowske, MD ${ }^{1,4}$ \\ 'Department of Epidemiology and Biostatistics, University of California, San Francisco, CA, USA; ${ }^{2}$ Division of Geriatrics, San Francisco VA Medical \\ Center and the University of California, San Francisco, CA, USA; ${ }^{3}$ School of Public Health, University of California, Berkeley, CA, USA; ${ }^{4}$ Division of \\ General Internal Medicine, VA Medical Center, University of California, San Francisco, CA, USA.
}

OBJECTIVE: We conducted a systematic review to assess the quality and limitations of published studies examining benefits and harms of screening mammography in relation to comorbidity and age.

METHODS: We searched MEDLINE and EMBASE from January 1980 through June 2013 for studies that examined benefits or harms of screening mammography in women aged 65 years or older in relation to comorbidity. For each study, we extracted data regarding setting, design, quality, screening schedule, measure of comorbidity, and estimates of benefits and/or harms. We reviewed 1760 titles, identifying 7 articles that met the inclusion criteria: prospective cohort (two studies), retrospective cohort (two studies), and decision analyses (three studies). No randomized controlled trials were identified.

RESULTS: At least one measure of life expectancy or reduction in the risk of breast cancer death as a marker of benefit was examined in four studies, whereas three studies addressed the harms of screening mammography, including false-positive results. Both cohort studies and decision analyses showed that screening benefits decreased with increasing age and comorbidity burden.

CONCLUSIONS: The limited evidence currently available suggests that, apart from older women with severe comorbidity, women 65 and older may experience improvements in life expectancy from screening. Given the potential for harm, it is unclear whether the magnitude of the benefit is sufficient to warrant regular screening. Women, clinicians and policymakers should consider these factors in deciding whether continue screening.

KEY WORDS: breast cancer screening; comorbidity; aging.

J Gen Intern Med 31(5):561-72

DOI: $10.1007 /$ s11606-015-3580-3

(c) Society of General Internal Medicine 2016

\section{INTRODUCTION}

Almost half of new invasive breast cancer cases diagnosed each year in the United Sates occur among women aged 65 years and older (hereafter referred to as older women),

Received March 13, 2015

Revised June 23, 2015

Accepted December 8, 2015

Published online January 29, 2016 and rates rise with advancing age. ${ }^{1}$ With the increasing life expectancy and aging of women in the U.S. and globally, the absolute number of breast cancer cases among older women is expected to increase over the coming decades. These dual demographic and epidemiologic forces, coupled with heterogeneity in health and the lack of direct evidence for screening efficacy among women aged 70 and older, create a clinical and policy conundrum: is there a combination of comorbidity and age when women should stop screening because the harms outweigh the benefits? $?^{2,3}$ Age-related differences in comorbidity and tumor biology, variance in women's preferences for health outcomes associated with breast cancer screening, and increasing health care costs add to the challenge in answering this question. ${ }^{2-8}$

Numerous factors including tumor size, involvement of regional lymph nodes, histologic grade, expression of hormone receptors (estrogen and progesterone), and human epidermal growth factor receptor 2 (HER2) amplification are used to determine which women with early-stage breast cancer should be treated with adjuvant systemic therapy, including endocrine therapy, chemotherapy, and HER2-directed treatments. ${ }^{9}$ Importantly, older patients with comorbidities often experience complications from virtually all treatment modalities. ${ }^{10-12}$ Although one of the advantages of early diagnosis includes identifying tumors with favorable prognostic markers and risk assessment scores, ${ }^{9}$ such benefits may not be realized in older women with substantial comorbidity due to their short life expectancy. ${ }^{4}$ The harms of screening are often immediate, and include false-positive results and overdiagnosis. ${ }^{13-17}$ Given the increasing comorbidity burden and attendant decline in life expectancy, many older women are unlikely to have a favorable ratio of benefits and harms. Additionally, rates of clinically indolent invasive tumors and ductal carcinoma in situ (DCIS) increase with age, raising the concern that older women are likely to be harmed from overdiagnosis and unnecessary treatment. ${ }^{16}$ Robust evidence regarding the efficacy of screening mammography in older women is lacking because randomized controlled trials have not included women over age 74 years and those with substantial comorbidity. ${ }^{18}$

The extent to which benefits and harms of breast cancer screening in older women vary according to comorbidity and 
age is not well established. To better target health services to those who may benefit, it is important that screening mammography practices in older women incorporate patient factors such as comorbidity and age, which are important predictors of life expectancy. Our purpose here is to report the results of a systematic review of the literature examining the impact of comorbidity and age on screening mammography outcomes in older women. Limitations of previous studies and future directions are also discussed.

\section{METHODS}

\section{Search Strategy and Selection Criteria}

Our research question was: Do the benefits and harms of screening mammography in older women vary according to comorbidity and age? We performed a systematic search of the literature using PubMed and EMBASE (January 1, 1980, to July 1,2013 ) to identify relevant studies in all languages. The term "breast neoplasms" was combined with the permutations, variations, and abbreviations of the relevant $\mathrm{MeSH}$ keywords and non-MeSH key terms for mammography, age, and comorbidity, including specific conditions (e.g., cardiovascular diseases, cognition disorders, diabetes mellitus, health status, heart diseases, hypertension, myocardial infarction, stroke) or comorbidity summary scores. Severe comorbidity was defined as a Charlson score of $\geq 3$ and the presence of AIDS, mild or severe liver disease, chronic obstructive pulmonary disease, chronic renal failure, dementia, or congestive heart failure. A Charlson score of 3 or higher also represents severe comorbidity.

Additional studies were obtained through citations of review articles or by contacting experts in the field regarding any unpublished articles that might be suitable for inclusion in the systematic review.

For each study, two authors (MI and DB) independently abstracted data regarding study eligibility and outcomes to determine relevance. We set a priori broad inclusion criteria permitting any study design, including decision analyses that (i) included women aged 65 and older, (ii) assessed women's comorbidity (either as a specific condition or a summary score), and (iii) reported at least one of the following outcomes: (a) tumor stage at diagnosis, (b) reassurance about negative results, (c) life expectancy and/or quality-adjusted life expectancy, (d) mortality, and (e) number needed to screen to gain one life-year. We also evaluated studies that assessed harms as outcomes, specifically (a) false-positive results, (b) false-positive biopsy, and (c) overdiagnosis. We excluded studies of women with a history of breast cancer.

To evaluate the quality of observational studies, we used the Newcastle-Ottawa Scale (NOS), ${ }^{19}$ in which a study is judged within three broad perspectives: (i) the selection of the study groups (representativeness of the exposed cohort, selection of the non-exposed cohort, and ascertainment of the exposure and demonstration that the outcome of interest was present); (ii) the comparability of the groups (comparability of cohorts on the basis of the design or analysis); and (iii) the ascertainment of either the exposure or outcome of interest (assessment of outcome, whether follow-up was long enough for outcomes to occur, and adequacy of follow-up of cohorts). Whereas a study can receive one star for meeting each criterion (*), the exception is comparability, for which a study receives one star if the study controlled for age, and two stars if the study also controlled for other important factors. Studies with a score of 5 and above (of a total of 9) are considered of moderate to high quality.

The included decision analyses were critically appraised according to criteria outlined by Richardson and Detsky ${ }^{20}$ and Justice et al. ${ }^{21}$ with modification to include the suggestion of Justice et al. ${ }^{21}$ - that models should be assessed for their transportability between populations, and that if valid, they should accurately predict events in populations other than the one in which the model was developed. This appraisal method was previously used in a systematic review of benefits and harms of screening mammography in older women. ${ }^{22}$

\section{RESULTS}

We identified 1760 potentially relevant abstracts through EMBASE and 398 through MEDLINE (see PRISMA flowchart in Fig. 1). After excluding studies with participants whose average age was less than 65 years, those that did not evaluate breast cancer or mammography screening, those that evaluated outcomes other than benefits or harms of screening, and those that did not report on comorbidity, there were 21 remaining studies published between 1980 and 2013,,$^{3,15,17,23-}$ ${ }^{39}$ with one article in the process of publication at the time of the literature search, which has since been published. ${ }^{40}$ Reviews of the full texts of these studies resulted in the exclusion of 14 studies, ${ }^{3,17,23-34}$ leaving 7 studies ${ }^{15,35-40}$ (Fig. 1). Characteristics of the included studies are shown in Table 1. All four cohort studies ${ }^{15,35-37}$ involved U.S. study populations, and all three decision analyses ${ }^{38-40}$ employed U.S.-based population estimates. None of the studies were clinical trials.

\section{Quality Assessment}

All four cohort studies scored 5 points or more based on the NOS criteria, indicating moderate to good study quality. ${ }^{19}$ A summary of the quality scoring criteria for cohort studies is provided in Table 2. In all cohort studies, downgrading of the evidence was due to a lack of adjustment for important confounding factors. Table 3 presents a critical appraisal of the decision analyses estimating life expectancy gains from screening mammography in older U.S. women. All decision-analytic studies conducted sensitivity analyses, and used U.S. estimates of prior probabilities, utilities, and other parameters in models, and were considered of good quality. 


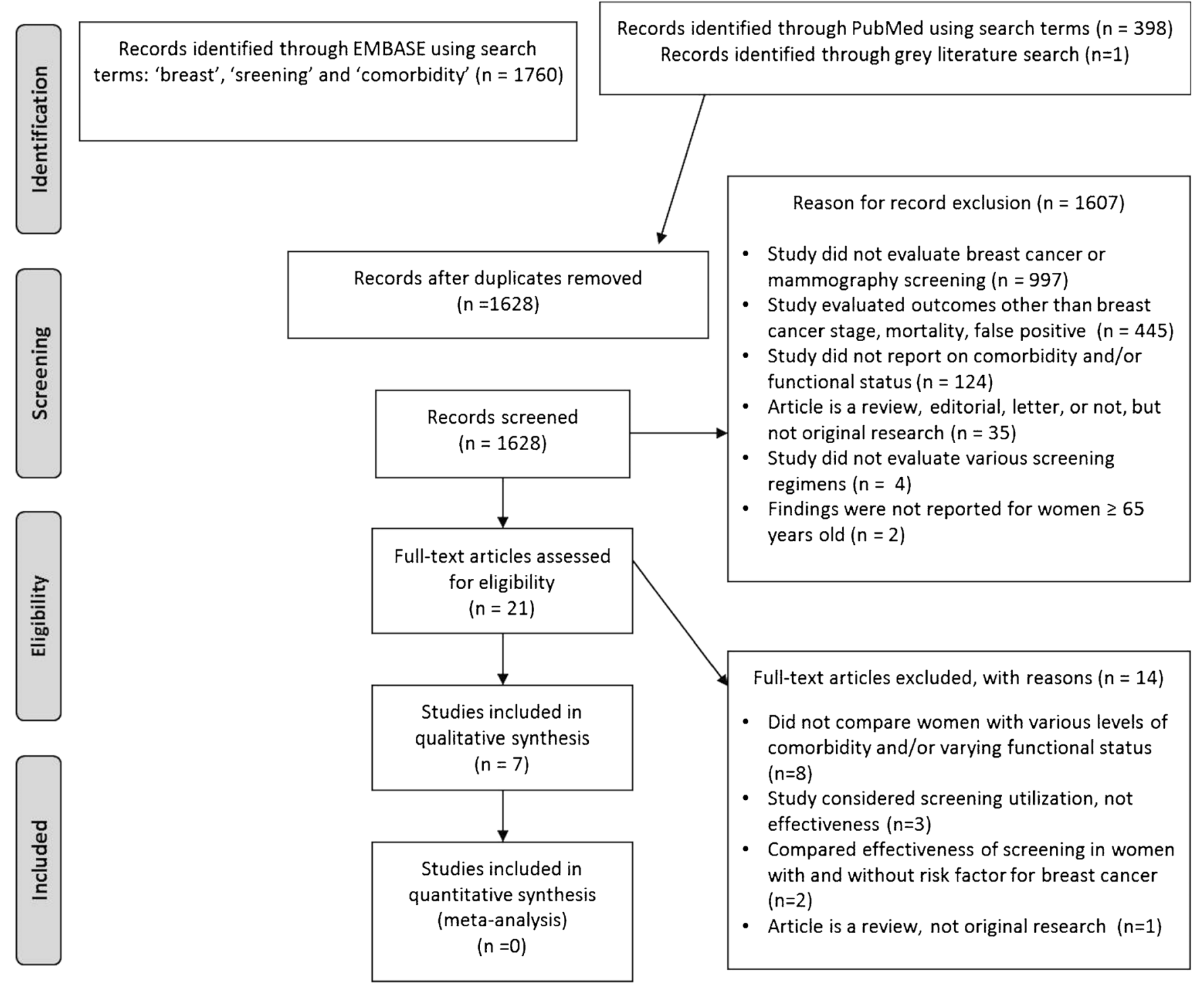

Figure 1 PRISMA flow diagram: description of the literature search.

\section{Estimates of Screening Mammography Benefits from Cohort Studies}

\section{Benefit Estimates by Breast Cancer Mortality (Table 4).}

In a study by McPherson et al. ${ }^{37}$ reporting on 5186 women aged 65 years and older who were diagnosed with breast cancer between 1986 and 1994 through the Upper Midwest Tumor Registry system, women's comorbidity was assessed via the Charlson Comorbidity Score (CCS). ${ }^{41}$ In this study, women aged $\geq 65$ with no or moderate comorbidity and mammography-detected tumors were found to be at reduced risk of breast cancer death compared to those with clinically detected (palpable) tumors. ${ }^{37}$ Furthermore, among women with severe comorbidity, as defined by a CCS score of $\geq 3$, mammography screening was associated with reduced breast cancer mortality among women aged $70-74$ years, but not in those aged $<70$ or $>74$ years. ${ }^{37}$
Benefit Estimates by Tumor Stage. Of the three studies that evaluated the risk of early versus advanced tumor stage, ${ }^{15,35,36}$ two-Braithwaite et al. and Yasmeen et al.- used data from the Breast Cancer Surveillance Consortium (BCSC) mammography registries that participated in a linkage with Medicare claims between 1999 and 2006, ${ }^{15,36}$ where information on comorbidities was obtained from Medicare claims in the 2 years before screening mammography. In another cohort study, Flemming et al. merged data from the Surveillance, Epidemiology and End Results (SEER) program with Medicare claims for 17,468 women diagnosed with breast cancer between 1993 and $1995 .{ }^{35}$ Heterogeneous measures of comorbidity were utilized: Braithwaite et al. employed the $\mathrm{CCS},{ }^{15,37,41}$ while Flemming et $\mathrm{al}^{35}$ and Yasmeen et $\mathrm{al}^{36}$ reported on 24 individual conditions and severity-based categorizations of comorbidity, respectively. 
Table 1 Characteristics of Studies Identified in Literature Search

\begin{tabular}{|c|c|c|c|c|c|c|c|c|c|}
\hline Source & Setting & $\begin{array}{l}\text { No. } \\
\text { enrolled }\end{array}$ & $\begin{array}{l}\text { Study } \\
\text { design }\end{array}$ & $\begin{array}{l}\text { Years of } \\
\text { accrual }\end{array}$ & $\begin{array}{l}\text { Age } \\
\text { range, } \\
\text { years }\end{array}$ & $\begin{array}{l}\text { Length } \\
\text { of follow- } \\
\text { up }\end{array}$ & $\begin{array}{l}\text { Measures of } \\
\text { comorbidity }\end{array}$ & $\begin{array}{l}\text { Screening } \\
\text { regimens } \\
\text { compared }\end{array}$ & $\begin{array}{l}\text { Outcome(s) } \\
\text { of interest } \\
\text { reported }\end{array}$ \\
\hline \multicolumn{10}{|c|}{ Cohort studies } \\
\hline $\begin{array}{l}\text { McPherson, } \\
2002\end{array}$ & USA & 5186 & $\begin{array}{l}\text { Retrospective } \\
\text { cohort }\end{array}$ & 1986-1994 & $65-101$ & $\begin{array}{l}1 \text { month } \\
\text { to } 10.9 \\
\text { years }\end{array}$ & $\begin{array}{l}\text { Charlson } \\
\text { Comorbidity } \\
\text { Score }\end{array}$ & $\begin{array}{l}\text { Mammographic } \\
\text { vs. clinical } \\
\text { (palpation) } \\
\text { diagnosis }\end{array}$ & Risk of death \\
\hline $\begin{array}{l}\text { Fleming, } \\
2005\end{array}$ & USA & 17,468 & $\begin{array}{l}\text { Retrospective } \\
\text { cohort }\end{array}$ & 1993-1995 & $\geq 67$ & - & $\begin{array}{l}24 \text { conditions } \\
\text { (listed in Table } 4 \text { ) }\end{array}$ & $\begin{array}{l}\text { Diagnostic } \\
\text { mammography } \\
\text { vs. screening } \\
\text { mammography }\end{array}$ & $\begin{array}{l}\text { Late-stage } \\
\text { (regional } \\
\text { and distant) } \\
\text { vs. early-stage } \\
\text { (in situ and } \\
\text { local) breast } \\
\text { cancer }\end{array}$ \\
\hline $\begin{array}{l}\text { Yasmeen, } \\
2012\end{array}$ & USA & 149,045 & $\begin{array}{l}\text { Prospective } \\
\text { cohort }\end{array}$ & 1998-2006 & $\geq 67$ & $\begin{array}{l}1-6 \\
\text { years }\end{array}$ & $\begin{array}{l}\text { Unstable (life- } \\
\text { threatening } \\
\text { conditions such } \\
\text { as severe heart } \\
\text { failure, cardiac } \\
\text { arrhythmias, } \\
\text { end-stage liver } \\
\text { disease), stable } \\
\text { (conditions that } \\
\text { could affect } \\
\text { daily function } \\
\text { such as diabetes, } \\
\text { depression, arthritis, } \\
\text { osteoporosis), or } \\
\text { none }\end{array}$ & $\begin{array}{l}\text { 1-year interval } \\
\text { vs. } 2 \text {-year } \\
\text { interval vs. } \\
3 \text {-year interval } \\
\text { vs. }>3 \text { years or } \\
\text { first screening } \\
\text { mammography } \\
\text { vs. }>3 \text { years or } \\
\text { first diagnostic } \\
\text { mammography }\end{array}$ & $\begin{array}{l}\text { Advanced- } \\
\text { (stages IIB-- } \\
\text { IV) vs. early- } \\
\text { stage (stages } \\
\text { I-IIA) breast } \\
\text { cancer }\end{array}$ \\
\hline $\begin{array}{l}\text { Braithwaite, } \\
2013\end{array}$ & USA & 140,942 & $\begin{array}{l}\text { Prospective } \\
\text { cohort }\end{array}$ & 1999-2006 & $66-89$ & $\begin{array}{l}1-10 \\
\text { years }\end{array}$ & $\begin{array}{l}\text { Charlson } \\
\text { Comorbidity } \\
\text { Score }\end{array}$ & $\begin{array}{l}\text { 1-year interval } \\
\text { vs. 2-year } \\
\text { interval }\end{array}$ & $\begin{array}{l}\text { 1. Invasive breast } \\
\text { cancer vs. ductal } \\
\text { carcinoma in situ } \\
\text { (DCIS) } \\
2 \text {. Advanced- } \\
\text { (stages IIB-IV) } \\
\text { vs. early-stage } \\
\text { (stages I-IIA) } \\
\text { breast cancer } \\
\text { 3. Large }(>20 \mathrm{~mm}) \\
\text { vs. small ( } \leq 20 \mathrm{~mm}) \\
\text { tumors } \\
4 \text {. Lymph node } \\
\text { involvement vs. } \\
\text { no } \\
5 \text {. False-positive } \\
\text { recall } \\
6 . \text { False-positive } \\
\text { biopsy recommenda- } \\
\text { tion }\end{array}$ \\
\hline \multicolumn{10}{|c|}{ Decision-analytic models } \\
\hline $\begin{array}{l}\text { Mandelblatt, } \\
1992\end{array}$ & USA & - & $\begin{array}{l}\text { Decision- } \\
\text { analytic } \\
\text { model }\end{array}$ & $1975-1984$ & $\geq 65$ & - & $\begin{array}{l}\text { Average } \\
\text { comorbidity } \\
\text { (mortality equal } \\
\text { to that of the } \\
\text { general population), } \\
\text { mild hypertension } \\
\text { (mild comorbidity), } \\
\text { congestive heart } \\
\text { failure (major } \\
\text { comorbidity) }\end{array}$ & $\begin{array}{l}\text { Screening vs. } \\
\text { no screening }\end{array}$ & $\begin{array}{l}\text { 1. Marginal savings } \\
\text { in life expectancy } \\
\text { 2. Long-term } \\
\text { quality-adjusted } \\
\text { marginal savings } \\
\text { in life expectancy } \\
\text { 3. Long- and short- } \\
\text { term adjusted } \\
\text { marginal savings } \\
\text { in life expectancy }\end{array}$ \\
\hline $\begin{array}{l}\text { Messecar, } \\
2000\end{array}$ & USA & - & $\begin{array}{l}\text { Decision- } \\
\text { analytic } \\
\text { model }\end{array}$ & - & $\geq 75$ & 10 years & $\begin{array}{l}\text { Cognitive impairment } \\
\text { vs. no cognitive } \\
\text { impairment }\end{array}$ & $\begin{array}{l}\text { One additional } \\
\text { screening } \\
\text { following } \\
\text { regular biennial } \\
\text { screening vs. no } \\
\text { prior screening }\end{array}$ & $\begin{array}{l}\text { Quality-adjusted } \\
\text { savings in life } \\
\text { expectancy }\end{array}$ \\
\hline
\end{tabular}


Table 1. (continued)

\begin{tabular}{|c|c|c|c|c|c|c|c|c|c|}
\hline Source & Setting & $\begin{array}{l}\text { No. } \\
\text { enrolled }\end{array}$ & $\begin{array}{l}\text { Study } \\
\text { design }\end{array}$ & $\begin{array}{l}\text { Years of } \\
\text { accrual }\end{array}$ & $\begin{array}{l}\text { Age } \\
\text { range, } \\
\text { years }\end{array}$ & $\begin{array}{l}\text { Length } \\
\text { of follow- } \\
\text { up }\end{array}$ & $\begin{array}{l}\text { Measures of } \\
\text { comorbidity }\end{array}$ & $\begin{array}{l}\text { Screening } \\
\text { regimens } \\
\text { compared }\end{array}$ & $\begin{array}{l}\text { Outcome(s) } \\
\text { of interest } \\
\text { reported }\end{array}$ \\
\hline $\begin{array}{l}\text { Lansdorp- } \\
\text { Vogelaar, } \\
2014\end{array}$ & USA & - & $\begin{array}{l}\text { Decision- } \\
\text { analytic } \\
\text { models }\end{array}$ & - & $50-90$ & - & $\begin{array}{l}\text { None, mild (history } \\
\text { of myocardial } \\
\text { infarction [MI], } \\
\text { acute MI, ulcer or } \\
\text { rheumatologic } \\
\text { disease), moderate } \\
\text { (cardiovascular } \\
\text { disease, paralysis, } \\
\text { diabetes), or } \\
\text { severe comorbidity } \\
\text { (AIDS, chronic } \\
\text { obstructive } \\
\text { pulmonary disease, } \\
\text { mild/severe liver } \\
\text { disease, renal failure, } \\
\text { dementia, congestive } \\
\text { heart failure) }\end{array}$ & $\begin{array}{l}\text { Biennial } \\
\text { screening } \\
\text { from age } \\
50 \text { to cessation } \\
\text { age ranging } \\
\text { from } 66 \text { to } 90\end{array}$ & $\begin{array}{l}\text { 1. Incremental } \\
\text { life-years gained } \\
\text { (LYG) } \\
\text { 2. Cancer deaths } \\
\text { prevented } \\
\text { 3. Incremental } \\
\text { number of } \\
\text { screening tests } \\
\text { 4. False-positive } \\
\text { screens } \\
\text { 5. Over-diagnosed } \\
\text { cases } \\
6 . \text { Number needed } \\
\text { to screen to gain } \\
\text { one life-year } \\
\text { (NNS/LYG) in } \\
\text { the population }\end{array}$ \\
\hline
\end{tabular}

Yasmeen et al. found that overall rates (per 1000 mammograms) of advanced breast cancer were lower among women with no comorbidity than among those with stable comorbidity in annually and biennially screened women and those that received their first screen. ${ }^{36}$ However, among women who had previously undergone mammography within 4 to 18 months of cancer diagnosis, the rates of advanced-stage cancer were higher among those with either stable or unstable comorbidities than among those without comorbidities. ${ }^{36}$ In contrast, in another BCSC study, Braithwaite et al. ${ }^{15}$ reported that adverse tumor characteristics, including advanced stage, did not differ significantly by CCS or screening interval. ${ }^{15}$

Finally, Fleming et al. ${ }^{35}$ reported that women with cardiovascular disease, musculoskeletal disorders, mild-to-moderate gastrointestinal disease, and non-malignant benign breast disease had $13,7,14$, and $24 \%$ lower odds, respectively, of being diagnosed with advanced breast cancer, while those with diabetes, other endocrine disorders, psychiatric disorders, or hematologic disorders had higher odds of advanced-stage diagnosis by $19,11,20$, and $19 \%$, respectively, compared to women without these comorbidities.

\section{Estimates of Screening Mammography Benefits from Decision Analyses}

Benefit Estimates by Life Expectancy (Table 4). Two decision analyses in this systematic review, Mandelblatt et al. ${ }^{39}$ and Lansdorp-Vogelaar et al., ${ }^{40}$ employed well-established, independently developed models that are part of the Cancer Intervention and Surveillance Modeling Network (CISNET), with each model simulating the life histories of large U.S. cohorts, and assessing the underlying disease in the presence and absence of screening.

In the only contemporary study examining the harms and benefits of stopping mammography according to comorbidity, Lansdorp-Vogelaar et al. compared the number needed to screen per life-year gained at different stopping ages and

Table 2 Critical Evaluation of the Quality and Limitations of the Cohort Studies Evaluating Benefits and Harms of Screening Mammography According to Comorbidity

\begin{tabular}{|c|c|c|c|c|c|c|c|c|c|}
\hline \multirow[b]{2}{*}{ Source } & \multicolumn{4}{|l|}{ Selection } & \multirow{2}{*}{$\begin{array}{l}\text { Comparability } \\
\text { of cohorts }\end{array}$} & \multicolumn{3}{|l|}{ Outcome } & \multirow[t]{2}{*}{ NOS $^{\dagger}$} \\
\hline & $\begin{array}{l}\text { Exposed } \\
\text { cohort } \\
\text { representative }\end{array}$ & $\begin{array}{l}\text { Non-exposed } \\
\text { cohort } \\
\text { representative }\end{array}$ & $\begin{array}{l}\text { Exposure } \\
\text { ascertainment }\end{array}$ & $\begin{array}{l}\text { Demonstration } \\
\text { that outcome of } \\
\text { interest was not } \\
\text { present at start }\end{array}$ & & Assessment & $\begin{array}{l}\text { Follow-up } \\
\text { length }\end{array}$ & $\begin{array}{l}\text { Follow-up } \\
\text { adequacy }\end{array}$ & \\
\hline $\begin{array}{l}\text { McPherson, } \\
2002\end{array}$ & $*$ & $*$ & $*$ & & $*$ & $*$ & $*$ & $*$ & 7 \\
\hline $\begin{array}{l}\text { Fleming, } \\
2005\end{array}$ & $*$ & $*$ & $*$ & $*$ & $*$ & $*$ & $*$ & $*$ & 8 \\
\hline $\begin{array}{l}\text { Yasmeen, } \\
2012\end{array}$ & $*$ & $*$ & $*$ & $*$ & $*$ & $*$ & $*$ & $*$ & 8 \\
\hline $\begin{array}{l}\text { Braithwaite, } \\
2013\end{array}$ & $*$ & $*$ & $*$ & $*$ & $*$ & $*$ & $*$ & $*$ & 8 \\
\hline
\end{tabular}

${ }^{\dagger}$ Newcastle-Ottawa Quality Assessment Scale: study can have one star (*) for meeting each criterion in the selection and outcome categories. Comparability has a maximum of two stars. In this review, one star was given if a study controlled for age and two stars if it controlled for other important factors 
Table 3 Critical Evaluation of the Quality and Limitations of the Decision-Analytic Models Evaluating Benefits and Harms of Screening Mammography According to Comorbidity

\begin{tabular}{|c|c|c|c|c|c|}
\hline Source & $\begin{array}{l}\text { Were important strategies } \\
\text { included? }\end{array}$ & $\begin{array}{l}\text { Was the potential impact of } \\
\text { uncertainty in the evidence } \\
\text { determined? }\end{array}$ & $\begin{array}{l}\text { How strong is the } \\
\text { evidence? }\end{array}$ & $\begin{array}{l}\text { Do the probabilities } \\
\text { fit the U.S. } \\
\text { population? }\end{array}$ & $\begin{array}{l}\text { Do the utilities* } \\
\text { reflect the } \\
\text { values of older } \\
\text { women in the } \\
\text { U.S.? }\end{array}$ \\
\hline $\begin{array}{l}\text { Mandelblatt, } \\
1992\end{array}$ & $\begin{array}{l}\text { Yes - compared screening for } \\
\text { women } \geq 65 \text { years with no } \\
\text { screening }\end{array}$ & $\begin{array}{l}\text { Conducted sensitivity analyses } \\
\text { by varying quality of life, breast } \\
\text { cancer incidence rates, } \\
\text { perioperative death rate, } \\
\text { sensitivity and specificity of } \\
\text { mammography test, stage } \\
\text { distribution of detected breast } \\
\text { cancer }\end{array}$ & $\begin{array}{l}\text { The evidence is strong, } \\
\text { as the model assumes } \\
\text { U.S. breast cancer stage } \\
\text { distribution and stage- } \\
\text { specific survival data }\end{array}$ & $\begin{array}{l}\text { All measures used in } \\
\text { models were based } \\
\text { on U.S. population } \\
\text { estimates }\end{array}$ & Yes \\
\hline $\begin{array}{l}\text { Messecar, } \\
2000\end{array}$ & $\begin{array}{l}\text { Yes - compared } 1 \text { mammography } \\
\text { screening in women } \geq 75 \text { years } \\
\text { with and without cognitive } \\
\text { impairment, who (a) underwent } \\
\text { regular screening, or (b) had no } \\
\text { prior screening }\end{array}$ & $\begin{array}{l}\text { Conducted sensitivity analyses } \\
\text { by varying prior probabilities, } \\
\text { quality of life, costs of } \\
\text { recurrence, sensitivity and } \\
\text { specificity of mammography } \\
\text { test }\end{array}$ & $\begin{array}{l}\text { The evidence is strong, } \\
\text { as the model assumes } \\
\text { U.S. breast cancer stage } \\
\text { distribution and stage- } \\
\text { specific survival data }\end{array}$ & $\begin{array}{l}\text { All measures used in } \\
\text { models were based } \\
\text { on U.S. population } \\
\text { estimates }\end{array}$ & Yes \\
\hline $\begin{array}{l}\text { Lansdorp- } \\
\text { Vogelaar, } \\
2014\end{array}$ & $\begin{array}{l}\text { Yes - compared biennial } \\
\text { mammography screening from } \\
\text { age } 50 \text { to a range of cessation } \\
\text { ages from } 66 \text { to } 90\end{array}$ & $\begin{array}{l}\text { Assessed the robustness of } \\
\text { choice of metric by considering } \\
\text { other harms (false-positive tests, } \\
\text { over-diagnosed cancers) and } \\
\text { benefits (cancer deaths } \\
\text { prevented). Also varied method } \\
\text { of extrapolating comorbidity- } \\
\text { specific life tables }\end{array}$ & $\begin{array}{l}\text { The evidence is strong, } \\
\text { as the models assume } \\
\text { U.S. breast cancer stage } \\
\text { distribution and stage- } \\
\text { specific survival data }\end{array}$ & $\begin{array}{l}\text { All measures used in } \\
\text { models were based } \\
\text { on U.S. population } \\
\text { estimates }\end{array}$ & Yes \\
\hline
\end{tabular}

* Weights used to adjust life expectancy gains for impact on quality of life

estimated threshold stopping ages according to the level of comorbidity, at which the number needed to screen per lifeyear gained was the same as mammography until age 74 for women of average comorbidity. ${ }^{40}$ The authors evaluated biennial mammography screening from age 50 to a cessation age ranging from 66 to 90 by simulating U.S. cohorts of women who were 66-90 years of age and alive in 2010, and had no comorbidity, mild comorbidity (a history of myocardial infarction, acute myocardial infarction, ulcer, or rheumatologic disease), moderate comorbidity (the presence of vascular disease, cardiovascular disease, paralysis, or diabetes), or severe comorbidity (the presence of AIDS, mild or severe liver disease, chronic obstructive pulmonary disease, chronic renal failure, dementia, or congestive heart failure), as well as comparison cohorts of women aged 74 and 76 years with average comorbidity. The authors found that, with breast cancer screening through age 74, the number needed to screen to gain one lifeyear among women with no comorbidity was 117-149 across models, which was lower than in the entire population with average comorbidity; cessation of screening at age 76-78 years among women with no comorbidities was estimated to yield the same number needed to screen to gain one life-year as cessation at age 74 years in the entire population. ${ }^{40}$ Finally, this study pointed to the benefits of biennial mammography across models until median ages of 76-78, 74, 70-72, and 6468 years for women with no comorbidity, mild comorbidity, moderate comorbidity, and severe comorbidity, respectively. ${ }^{40}$

In hypothetical cohorts examining the benefits of biennial screening in terms of life-years, Mandelblatt et al. ${ }^{39}$ found that long- and short-term quality-adjusted savings in life expectancy from screening compared to a non-screening strategy were greater for older women with mild hypertension than for those with heart disease, and the benefit in both groups decreased with increasing age.

In another decision analysis examining three hypothetical cohorts of women aged 75-79, 80-84, and $\geq 85$ years, with and without cognitive impairment, Messecar et al. tested two models for each group, assuming no prior screening versus continued biennial screening. Whereas all older women benefited from biennial mammography screening, among women with no prior screening, the gain in quality-adjusted life-years was lower for cognitively impaired women $(20,9.1$, and 5.5 days for ages $75-79,80-84$, and $\geq 80$ years, respectively) than their healthy counterparts $(43.4,32.5$, and 25.9 days for ages $75-79,80-84$, and $\geq 80$ years, respectively). ${ }^{38}$

\section{Estimates of Screening Mammography Harms from Cohort Studies}

Harm Estimates by False-Positive Results (Table 4). In the only cohort study to evaluate the harms of screening mammography, Braithwaite et al. reported that the 10-year cumulative probability of a false-positive mammography result was higher among annual than biennial screeners, irrespective of comorbidity: $48.0 \%$ (95\% CI 46.1-49.9\%) of annual screeners aged 66 to 74 years had a false-positive result, compared with $29.0 \%$ (95\% CI 28.1-29.9\%) of biennial screeners. ${ }^{15}$ 
Table 4 Summary of Findings from Studies Evaluating the Benefits, Harms and the Balance of Benefits Versus Harms of Screening Mammography

\begin{tabular}{|c|c|c|c|c|c|}
\hline Source & Subgroups & \multicolumn{4}{|l|}{ Outcomes Reported } \\
\hline \multicolumn{6}{|l|}{ Benefits } \\
\hline \multirow{7}{*}{$\begin{array}{l}\text { McPherson, } \\
2002\end{array}$} & & \multicolumn{4}{|c|}{ Relative risk (RR) of death and $95 \%$ confidence interval $(\mathrm{CI})$} \\
\hline & Screening groups & \multicolumn{4}{|c|}{ Mammographic vs. clinical (palpation) diagnosis } \\
\hline & Comorbidity & No comorbidity & Moderate & \multicolumn{2}{|l|}{ Severe } \\
\hline & Ages: $65-69$ & $0.44(0.32-0.59)$ & $0.32(0.15-0.69)$ & \multicolumn{2}{|l|}{$0.41(0.11-1.48)$} \\
\hline & Ages: $70-74$ & $0.32(0.23-0.44)$ & $0.45(0.22-0.91)$ & \multicolumn{2}{|l|}{$0.30(0.11-0.79)$} \\
\hline & Ages: $75-79$ & $0.36(0.26-0.49)$ & $0.47(0.25-0.88)$ & \multicolumn{2}{|l|}{$0.53(0.20-1.36)$} \\
\hline & Ages: $\geq 80$ & $0.66(0.52-0.83)$ & $0.52(0.33-0.80)$ & \multicolumn{2}{|l|}{$0.64(0.30-1.87)$} \\
\hline \multirow[t]{12}{*}{ Fleming, 2005} & & \multicolumn{4}{|c|}{$\begin{array}{l}\text { Odds ratio (and } p \text { value) of late-stage (regional and distant) vs. early-stage (in situ and local) disease, } \\
\text { comorbid condition }\end{array}$} \\
\hline & $\begin{array}{l}\text { Screening groups } \\
\text { Comorbidity }\end{array}$ & $\begin{array}{l}\text { All patients were screened } \\
\text { Cardiovascular disease }\end{array}$ & Benign hypertension & Malignant hypertension & $\begin{array}{l}\text { Other vascular } \\
\text { disease }\end{array}$ \\
\hline & & $0.87(P<0.01)$ & $0.98(P<0.05)$ & $1.02(P>0.05)$ & $1.04(P>0.05)$ \\
\hline & & $\begin{array}{l}\text { Diabetes } \\
119(P<001)\end{array}$ & Endocrine disease & Neurological disease & Psychiatric dis \\
\hline & & Musculoskeletal disease & $\begin{array}{l}\text { Pulmonary disease, mild/ } \\
\text { moderate }\end{array}$ & $\begin{array}{l}\text { Pulmonary disease, } \\
\text { severe }\end{array}$ & $\begin{array}{l}\text { Gastrointestina } \\
\text { disease }\end{array}$ \\
\hline & & $0.93(P<0.01)$ & $1.08(P>0.05)$ & $0.99(P>0.05)$ & $0.86(P<0.01)$ \\
\hline & & $\begin{array}{l}\text { Benign breast disease, } \\
\text { nonmalignant }\end{array}$ & Genital-urinary disease & Obesity & AIDS \\
\hline & & $0.76(P<0.01)$ & $0.91(P>0.05)$ & $1.18(P>0.05)$ & $1.41(P>0.05)$ \\
\hline & & Cerebrovascular disease & Renal disease & $\begin{array}{l}\text { Gastrointestinal disease, } \\
\text { severe }\end{array}$ & Hematologic d \\
\hline & & $1.03(P>0.05)$ & $1.15(P>0.05)$ & $0.94(P>0.05)$ & $1.19(P<0.01)$ \\
\hline & & Osteoarthritis & Osteoporosis & Rheumatologic disease & Other cancers \\
\hline & & $0.96(P>0.05)$ & $1.16(P>0.05)$ & $1.02(P>0.05)$ & $1.04(P>0.05)$ \\
\hline \multirow[t]{8}{*}{ Yasmeen, 2012} & & \multicolumn{4}{|c|}{$\begin{array}{l}\text { Rates (per } 1000 \text { mammograms) and } 95 \% \text { confidence intervals for advanced (stages IIB-IV) vs. early } \\
\text { (stages I-IIA) breast cancer }\end{array}$} \\
\hline & Screening groups & \multirow{2}{*}{\multicolumn{2}{|c|}{$\begin{array}{l}\text { One additional screening } \\
\text { All } \quad \text { No comorbidities }\end{array}$}} & \multirow{3}{*}{ Stable comorbidities } & \multirow{3}{*}{$\begin{array}{l}\text { Unstable } \\
\text { comorbidities }\end{array}$} \\
\hline & Comorbidity & & No comorbidities & & \\
\hline & $\begin{array}{l}\text { Time since prior } \\
\text { screening }\end{array}$ & & & & \\
\hline & $4-18$ months ( 1 year) & $0.7(0.6-0.8)$ & $0.3(0.2-0.6)$ & $0.7(0.6-0.8)$ & $0.9(0.7-1.2)$ \\
\hline & $\begin{array}{l}19-30 \text { months } \\
(2 \text { years) }\end{array}$ & $0.9(0.7-1.2)$ & $0.4(0.1-1.5)$ & $0.9(0.6-1.3)$ & $1.0(0.6-1.6)$ \\
\hline & $31-42$ months & $1.6(1.1-2.4)$ & $2.2(0.8-5.9)$ & $1.0(0.5-1.9)$ & $2.7(1.6-4.7)$ \\
\hline & $>42$ months/first & $1.7(1.2-2.4)$ & $1.3(0.4-3.9)$ & $1.5(0.9-2.5)$ & $2.2(1.3-3.9)$ \\
\hline
\end{tabular}

Braithwaite, 2013

Mandelblatt, 1992

Odds ratio (OR) and $95 \%$ confidence interval (CI) for invasive breast cancer vs. ductal carcinoma in situ (DCIS)

2-year vs. 1-year interval

$\begin{array}{ll}\mathrm{CCS}=0 & \mathrm{CCS} \geq 1 \\ 0.83(0.59-1.17) & 0.92(0.54-1.56) \\ 1.07(0.71-1.60) & 1.02(0.51-2.03)\end{array}$

$1.07(0.71-1.60) \quad 1.02(0.51-2.03)$

Odds ratio (OR) and $95 \%$ confidence interval (CI) for advanced-stage (stages IIB-IV) vs. early-stage (stages

I-IIA) breast cancer

2 -year vs. 1-year interval

$\mathrm{CCS}=0 \quad \mathrm{CCS} \geq 1$

$0.75(0.46-1.22) \quad 0.99(0.48-2.04)$

$1.27(0.72-2.25) \quad 0.37(0.13-1.04)$

Odds ratio (OR) and $95 \%$ confidence interval $(\mathrm{CI})$ for large tumors $(>20 \mathrm{~mm})$ vs. small $(\leq 20 \mathrm{~mm})$

2-year vs. 1-year interval

$\mathrm{CCS}=0 \quad \mathrm{CCS} \geq 1$

$0.83(0.55-1.24) \quad 0.91(0.50-1.65)$

$1.30(0.83-2.05) \quad 1.38(0.70-2.73)$

Odds ratio (OR) and $95 \%$ confidence interval (CI) for positive lymph node involvement

2 -year vs. 1-year interval

$\mathrm{CCS}=0 \quad \mathrm{CCS} \geq 1$

$0.84(0.57-1.23) \quad 0.76(0.41-1.43)$

$0.83(0.51-1.33) \quad 0.62(0.29-1.34)$

Long-term quality-adjusted marginal savings in life expectancy (in days) and $95 \%$ confidence intervals (CI)

Ages: 66-74

Ages: $75-89$

Screening groups Comorbidity

Screening vs. no screening Average health

Mild hypertension

$2.19(1.97,2.41)$

$1.85(1.67,2.03)$

$1.43(1.30,1.57)$
$1.97(1.77,2.16)$

$1.68(1.51,1.84)$

$1.32(1.20,1.44)$
Congestive heart failure

$1.17(1.06,1.28)$

$1.08(0.98,1.18)$

$0.91(0.83,0.98)$
Average health (black)

$2.17(1.95,2.39)$

$2.22(1.99,2.44)$

$1.76(1.59,1.94)$ 
Table 4. (continued)

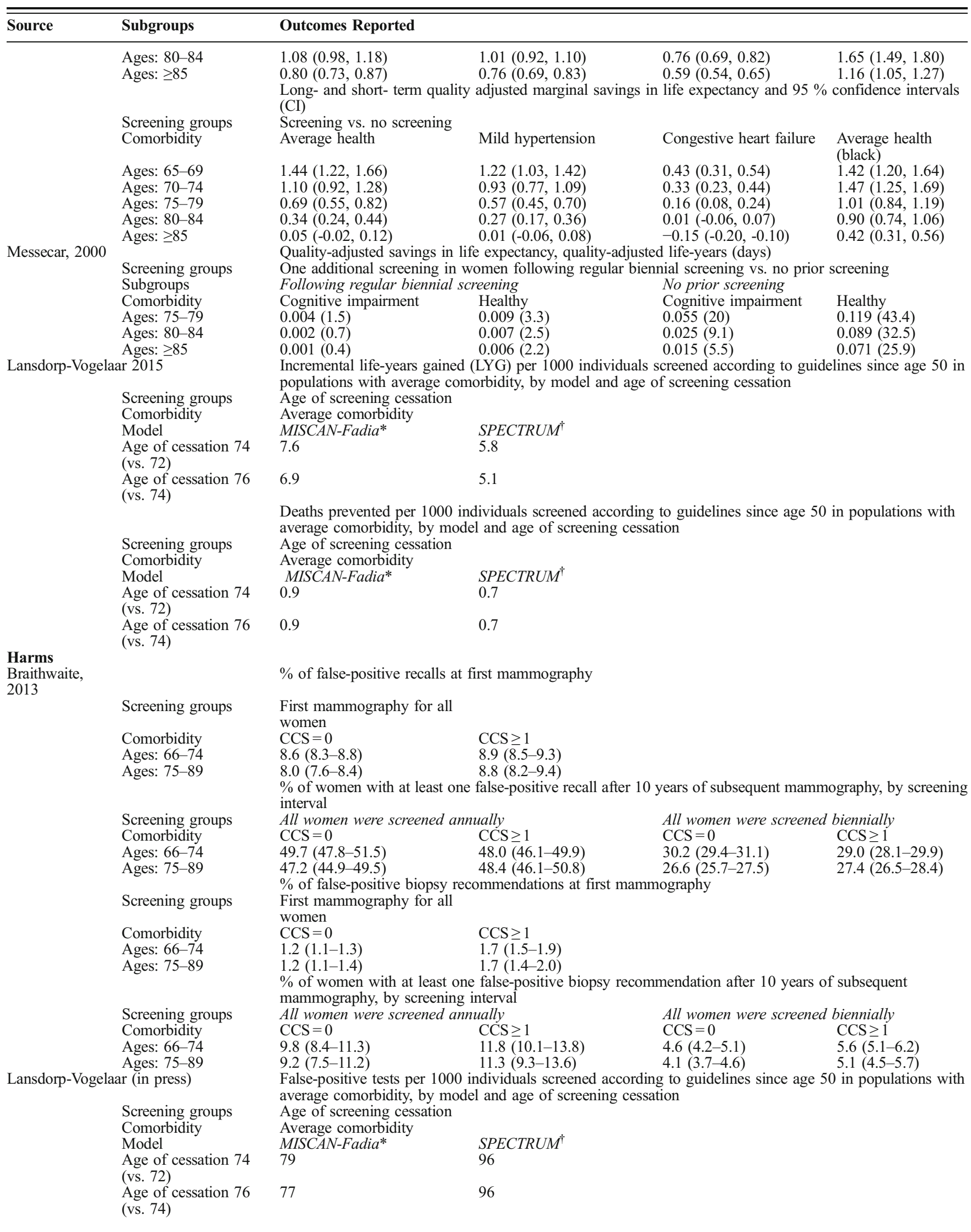


Table 4. (continued)

\begin{tabular}{|c|c|c|c|}
\hline Source & Subgroups & \multicolumn{2}{|l|}{ Outcomes Reported } \\
\hline & & \multicolumn{2}{|c|}{$\begin{array}{l}\text { Over-diagnosed cases per } 1000 \text { individuals screened according to guidelines since age } 50 \text { in populations with } \\
\text { average comorbidity, by model and age of screening cessation }\end{array}$} \\
\hline & Screening groups & \multicolumn{2}{|c|}{ Age of screening cessation } \\
\hline & Comorbidity & \multicolumn{2}{|c|}{ Average comorbidity } \\
\hline & Model & MISCAN-Fadia* & SPECTRUM \\
\hline & $\begin{array}{l}\text { Age of cessation } 74 \\
\text { (vs. } 72 \text { ) }\end{array}$ & 0.8 & 0.5 \\
\hline & $\begin{array}{l}\text { Age of cessation } 76 \\
\text { (vs. } 74 \text { ) }\end{array}$ & 1 & 0.6 \\
\hline \multicolumn{4}{|c|}{ Balance of benefits versus harms } \\
\hline \multicolumn{2}{|c|}{ Landsdorp-Vogelaar (2014) } & \multicolumn{2}{|c|}{ Number needed to screen to gain one life-year (NNS/LYG), by model and age of screening cessation } \\
\hline & Screening groups & \multicolumn{2}{|c|}{ Age of screening cessation } \\
\hline & Comorbidity & \multicolumn{2}{|c|}{ Average comorbidity } \\
\hline & Model & MISCAN-Fadia* & SPECTRUM ${ }^{\dagger}$ \\
\hline & Age of cessation 74 & 132 & 173 \\
\hline & $\begin{array}{l}\text { Age of cessation } 76 \\
\text { (vs. } 74 \text { ) }\end{array}$ & 146 & 198 \\
\hline
\end{tabular}

* MISCAN-Fadia: The MISCAN-Fadia model is a computer simulation program which incorporates information on the natural history of the disease as described by tumor stage and fatal tumor diameter (the size at which cancer becomes fatal) to construct models that compare the (cost-)effectiveness of different screening policies. It consists of four major components that simulate the demography and breast cancer incidence in the population, the natural history of a breast cancer tumor, the dissemination of mammography screening and its effects, and the dissemination of adjuvant treatment and its effects

'SPECTRUM: SPECTRUM is an event-driven continuous-time-state model which uses population-based estimates of breast cancer incidence and distribution of stage and other breast cancer characteristic (such as estrogen receptor status, response to treatment, and mortality) to estimate the efficacy of screening programs ${ }^{53}$

\section{Estimates of the Harms of Screening Mammography from Decision Analyses}

Harm Estimates by False-Positive Results (Table 4). In the only decision-analytic study to evaluate the harms of screening, Lansdorp-Vogelaar et $\mathrm{al}^{40}{ }^{40}$ showed that ending screening at age 74 versus 72 years resulted in 96 more false positive tests and 0.5 more over-diagnoses per 1000 screening tests.

\section{Balance of Benefits Versus Harms from Decision Analyses}

Lansdorp-Vogelaar et al. ${ }^{40}$ also estimated that extending breast cancer screening from age 72 to 74 years among individuals with average comorbidity required screening 132 to 174 women to gain one life-year; continuing screening until age 76 years required an additional 146-198 women screened to gain one life-year. ${ }^{40}$

\section{DISCUSSION}

As life expectancy continues to rise, it becomes increasingly important to determine the harms and benefits of preventive services such as screening mammography in older populations. The continuing controversy of whether to extend screening mammography to older women indicates a need to evaluate the extent to which benefits and harms of screening vary according to the extent and severity of comorbidity and age.
The evidence currently available from both cohort studies and decision-analytic models ${ }^{19,57-62}$ indicates that, apart from older women with severe comorbidity, women 65 and older may experience improved life expectancy from screening. Because studies in this synthesis were conducted over a long period of time, ranging from the mid-1970s to today, it is possible that outcomes may have been affected by the screening modality used, specifically film-screen versus digital mammography. However, the evidence has shown similar cancer detection rates with digital versus film-screen mammography among U.S. women aged 50-79 in the Breast Cancer Surveillance Consortium cohort. ${ }^{42}$

\section{Comorbidity and Benefits of Screening in Older Women}

Evidence points to a complex relationship between comorbidity and screening outcomes such as tumor stage at diagnosis and mortality, with variation linked to multiple patient factors including heterogeneous comorbidity measures, age, and screening intervals. Whereas Yasmeen et al. found that overall rates of advanced breast cancer were generally lower among women with no comorbidity versus those with stable comorbidity, Braithwaite et al. ${ }^{57}$ reported that adverse tumor characteristics, including advanced stage, did not differ significantly based on Charlson score or screening interval in the population-based BCSC cohort ${ }^{57}$. Moreover, Fleming et al..$^{58}$ reported that the odds of early versus advanced tumor stage varied across individual comorbid conditions, with diabetes and hematologic disorders showing the highest (19\% increased) odds of advanced-stage disease at diagnosis. Finally, 
in women with severe comorbidity, as defined by a Charlson score $\geq 3$, mammography screening was associated with reduced breast cancer mortality among women aged 70-74 years, but not in those aged $<70$ or $>74$ years $^{59}$. Consistent with observational data, decision-analytic models indicate that benefits were unlikely among women aged 65 years or older with severe comorbidity ${ }^{60-62}$. Specifically, in a decisionanalytic model, Lansdorp-Vogelaar et al. showed that the benefits of biennial mammography existed across models until median ages of 76-78 years, 74 years, 70-72 years, and 64-68 years for women with no comorbidity, mild comorbidity, moderate comorbidity, and severe comorbidity, respectively. ${ }^{61}$

\section{Comorbidity and Harms of Screening in Older Women}

Overall, there is a dearth of evidence on the harms of screening mammography in older women: only one cohort study ${ }^{15}$ and one decision model ${ }^{40}$ in this systematic review assessed screening harms according to comorbidity. Braithwaite et al. demonstrated that the cumulative 10 -year probability of a false-positive mammography result was approximately twice as high in biennially screened as in annually screened women aged 66 to 74 years, irrespective of comorbidity. ${ }^{15}$ While examining one of the hypothetical cohorts, LansdorpVogelaar et al. ${ }^{40}$ demonstrated that ending screening at age 74 versus 72 years resulted in 96 more false-positive tests and 0.5 more cases of overdiagnosis per 1000 screening tests. Because rates of clinically indolent tumors and ductal carcinoma in situ (DCIS) increase with age, older women are more likely to be harmed from overdiagnosis, ${ }^{16}$ defined as detection of tumors by screening that would not become clinically apparent during a woman's life or would not affect overall survival. Given the steeper rise in competing causes of mortality in women older than 74 , evidence suggests that rates of overdiagnosis are likely to be greater for older than for younger women. ${ }^{16,43}$

\section{Decision Making Regarding Benefits and Harms of Screening in Older Women}

Given the limited available evidence, the communication of potential benefits and harms to women in their $70 \mathrm{~s}$ and 80 s also poses a challenge. ${ }^{4,17,44-46}$ Clinical decisions among older populations about whether to undergo mammography may benefit from life expectancy-based screening strategies, especially given the evidence showing that screening mammography may not be targeted to the women who are most likely to benefit. ${ }^{47}$ One meta-analysis demonstrated that 10.7 years (4.4 to 21.6) on average was required before one death from breast cancer was prevented per 1000 women screened, which supports the notion that screening should be targeted to women with a life expectancy greater than 10 years. ${ }^{48}$ If these findings are replicated and confirmed with large-scale cohort data, women and their providers might consider the use of decision aids that accurately predict life expectancy in order to estimate a woman's risk of 10-year mortality and facilitate informed decisions about screening mammography. ${ }^{49-51}$

\section{Evidence Gaps}

This review has identified many areas related to screening mammography outcomes in older women that require additional research. Without randomized controlled trials, the benefits of continued screening mammography in women aged 75 and older will need to be ascertained from cohort data and simulation models. As noted in the recent Journal of the National Cancer Institute (JNCI) editorial, ${ }^{52}$ it will be important to eschew the pseudo-precision that direct application of microsimulation models can offer by combining empirical evidence with modeling. Moreover, moving the field forward will necessitate modeling screening performance (falsepositive rates, detection rates) and breast cancer survival as a function of comorbidity status and life expectancy, as well as the cost-effectiveness of various screening strategies according to comorbidity.

\section{Strengths and Limitations}

An important strength of this systematic review is that, to our knowledge, this is the first synthesis evaluating the extent to which benefits and harms of screening mammography vary according to comorbidity and age. It is important to recognize that observational data on screening mammography in older populations are subject to selection bias as well as lead-time and length bias. ${ }^{5}$ In observational studies evaluating screening mammography, the study populations of older women have self-selected to undergo mammography screening, and are thus likely healthier than the general U.S. population. Moreover, this systematic review identified heterogeneous studies with differing endpoints, which precluded us from synthesizing our results and estimating effects and bias quantitatively.

\section{Conclusions}

In summary, the limited evidence currently available suggests that, apart from the oldest women and those with severe comorbidity, women aged 65 and older may experience a slight increase in life expectancy from screening. Given the potential for harm, it is unclear whether the magnitude of the benefit is sufficient to warrant regular screening. Women, clinicians, and policymakers should consider these factors in deciding whether to continue screening. Because Medicare is required under the Affordable Care Act to pay for yearly mammography screening at no cost to women age $\geq 40$, with no upper age limit, ${ }^{1,2}$ screening harms may increase among older women with multiple comorbid conditions as a result of inappropriate screening utilization. Given that a randomized controlled trial of mammography in older women is unlikely, more highquality observational research examining innovative measures of life expectancy and contextual factors may facilitate an improved understanding of the benefits and harms of different screening mammography cessation ages and frequencies among older women and, 
ultimately, inform clinical and policy decisions about the appropriate use of screening in this growing population.

Acknowledgments: This research was supported by grant no. 121891-MRSG-12-007-01-CPHPS from the American Cancer Society (to Dr. Braithwaite). We thank Min-Lin Fang, MLS, and Gloria Won, MLS, for their assistance with the literature search, and Jisu Shin for administrative assistance. We are also grateful to Iris LansdorpVogelaar, $\mathrm{PhD}$, for her helpful comments on an earlier version of this manuscript.

Corresponding Author: Dejana Braithwaite, PhD; Department of Epidemiology and BiostatisticsUniversity of California, San Francisco, CA, USA (e-mail: DBraithwaite@epi.ucsf.edu).

\section{Compliance with ethical standards:}

Conflict of Interest: The funders had no role in the design or conduct of the study; collection, management, analysis, or interpretation of the data; or preparation, review, or approval of the manuscript. The authors declare that they do not have a conflict of interest.

\section{REFERENCES}

1. American Cancer Society: Cancer Facts and Figures, 2014

2. Walter LC, Covinsky KE. Cancer screening in elderly patients: a framework for individualized decision making. JAMA. 2001;285:2750-6.

3. Mandelblatt JS, Schechter CB, Yabroff KR, et al. Toward optimal screening strategies for older women. Costs, benefits, and harms of breast cancer screening by age, biology, and health status. J Gen Intern Med. 2005;20:487-96.

4. Braithwaite D, Mandelblatt JS, Kerlikowske K. To screen or not to screen older women for breast cancer: a conundrum. Future Oncol. 2013;9:763-6.

5. Mandelblatt JS, Silliman R. Hanging in the balance: making decisions about the benefits and harms of breast cancer screening among the oldest old without a safety net of scientific evidence. J Clin Oncol. 2009;27:48790.

6. Berry DA, Baines CJ, Baum M, et al. Flawed inferences about screening mammography's benefit based on observational data. J Clin Oncol. 2009;27:639-40. author reply 641-632.

7. Zappa M, Visioli $\mathbf{C B}$, Ciatto $\mathbf{S}$. Mammography screening in elderly women: Efficacy and cost-effectiveness. Crit Rev Oncol Hematol. 2003;46:235-9.

8. Walter LC, Schonberg MA. Screening mammography in older women: a review. JAMA. 2014;311:1336-47.

9. Cobain EF, Hayes DF. Indications for prognostic gene expression profiling in early breast cancer. Curr Treat Options Oncol. 2015;16:340.

10. Extermann M. Interaction between comorbidity and cancer. Cancer Control. 2007; 14:13-22.

11. Extermann M. Measurement and impact of comorbidity in older cancer patients. Crit Rev Oncol Hematol. 2000;35:181-200.

12. Satariano WA, Silliman RA. Comorbidity: Implications for research and practice in geriatric oncology. Crit Rev Oncol Hematol. 2003;48:239-48.

13. Etzioni R, Gulati R, Mallinger L, Mandelblatt J. Influence of study features and methods on overdiagnosis estimates in breast and prostate cancer screening. Ann Intern Med. 2013;158:831-8.

14. Hubbard RA, Kerlikowske K, Flowers CI, Yankaskas BC, Zhu W, Miglioretti DL. Cumulative probability of false-positive recall or biopsy recommendation after 10 years of screening mammography: a cohort study. Ann Intern Med. 2011;155:481-92.

15. Braithwaite D, Zhu W, Hubbard RA, et al. Screening Outcomes in Older US Women Undergoing Multiple Mammograms in Community Practice: Does Interval, Age or Comorbidity Score Affect Tumor Characteristics or False Positive Rates? J Natl Cancer Inst. 2013;105(5):334-41.

16. Mandelblatt JS, Cronin KA, Bailey S, et al. Effects of mammography screening under different screening schedules: model estimates of potential benefits and harms. Ann Intern Med. 2009;151:738-47.

17. Walter LC, Lewis CL, Barton MB. Screening for colorectal, breast, and cervical cancer in the elderly: a review of the evidence. Am $\mathrm{J}$ Med. 2005; 118:1078-86
18. Nelson HD, Tyne K, Naik A, Bougatsos C, Chan BK, Humphrey L. Screening for breast cancer: an update for the U.S. Preventive Services Task Force. Ann Intern Med. 2009;151:727-37. W237-742.

19. Wells GA, Shea B, O'Connell D, Peterson J, Welch V, Losos M, Tugwell P. The Newcastle-Ottawa Scale (NOS) for assessing the quality of nonrandomised studies in meta-analyses. http://www.ohri.ca/programs/ clinical'epidemiology/oxford.asp (accessed 11 Nov 2015).

20. Richardson W, Detsky A. Users' Guides to the Medical Literature: VII. How to use a clinical decision analysis. JAMA. 1992;273:1292-5.

21. Justice AC, Covinsky KE, Berlin JA. Assessing the generalizability of prognostic information. Ann Intern Med. 1999;130:515-24.

22. Barratt A, Irwig L, Glasziou $\mathbf{P}$, et al. Relative benefit of mammography reduces with age. Evid Based Healthc. 2002;6:156-7.

23. Kajbaf S, Nichol G, Zimmerman D. Cancer screening and life expectancy of Canadian patients with kidney failure. Nephrol Dial Transplant. 2002; 17:1786-9.

24. LeBrun CJ, Diehl LF, Abbott KC, Welch PG, Yuan CM. Life expectancy benefits of cancer screening in the end-stage renal disease population. Am J Kidney Dis. 2000;35:237-43.

25. Walter LC, Eng C, Covinsky KE. Screening mammography for frail older women: What are the burdens? J Gen Intern Med. 2001;16:779-84.

26. Yasmeen S, Xing G, Morris C, Chlebowski RT, Romano PS. Comorbidities and mammography use interact to explain racial/ethnic disparities in breast cancer stage at diagnosis. Cancer. 2011;117:3252-61.

27. Terret C, Castel-Kremer E, Albrand G, Droz JP. Effects of comorbidity on screening and early diagnosis of cancer in elderly people. Lancet Oncol. 2009; 10:80-7.

28. Smith-Bindman R, Guale C, Chu PW, Rosenberg R, Kerlikowske K. Can Medicare billing claims data be used to assess mammography utilization among women ages 65 and older? Med Care. 2006;44:463-70.

29. Schousboe JT, Kerlikowske K, Loh A, Cummings SR. Personalizing mammography by breast density and other risk factors for breast cancer: analysis of health benefits and cost-effectiveness. Ann Intern Med. 2011;155:10-20.

30. Kerlikowske K, Salzmann P, Phillips KA, Cauley JA, Cummings SR. Continuing screening mammography in women aged 70 to 79 years: impact on life expectancy and cost-effectiveness. JAMA. 1999;282:2156-63.

31. Walter LC, Lindquist $\mathbf{K}, \mathbf{O}^{\prime}$ Hare AM, Johansen $\mathbf{K L}$. Targeting screening mammography according to life expectancy among women undergoing dialysis. Arch Intern Med. 2006;166:1203-8.

32. Chertow GM, Paltiel AD, Owen WF Jr, Lazarus JM. Cost-effectiveness of cancer screening in end-stage renal disease. Arch Intern Med. 1996; 156: 1345-50.

33. Sennerstam RB, Wiksell H, Schassburger KU, Auer GU. Breast cancer and clinical outcome among women over 60 years of age a plead for more screening and alternative treatments. Anal Quant Cytol Histol. 2012;34:189-94.

34. Stout NK, Rosenberg MA, Trentham-Dietz A, Smith MA, Robinson SM, Fryback DG. Retrospective cost-effectiveness analysis of screening mammography. J Natl Cancer Inst. 2006;98:774-82.

35. Fleming ST, Pursley HG, Newman B, Pavlov D, Chen K. Comorbidity as a predictor of stage of illness for patients with breast cancer. Med Care. 2005;43:132-40.

36. Yasmeen S, Hubbard RA, Romano PS, et al. Risk of Advanced-Stage Breast Cancer among Older Women with Comorbidities. Cancer Epidemiol Biomarkers Prev. 2012.

37. McPherson CP, Swenson KK, Lee MW. The effects of mammographic detection and comorbidity on the survival of older women with breast cancer. J Am Geriatr Soc. 2002;50:1061-8.

38. Messecar DC. Mammography screening for older women with and without cognitive impairment. J Gerontol Nurs. 2000;26:14-24. quiz 52-13.

39. Mandelblatt JS, Wheat ME, Monane M, Moshief RD, Hollenberg JP, Tang J. Breast cancer screening for elderly women with and without comorbid conditions. A decision analysis model. Ann Intern Med. 1992;116:722-30.

40. Lansdorp-Vogelaar I, Gulati R, Mariotto AB, et al. Personalizing age of cancer screening cessation based on comorbid conditions: model estimates of harms and benefits. Ann Intern Med. 2014;161:104-12.

41. Charlson ME, Pompei P, Ales KL, Mackenzie CR. A new method of classifying prognostic comorbidity in longitudinal studies: development and validation. J Chronic Dis. 1987;40:373-83. 
42. Kerlikowske K, Hubbard RA, Miglioretti DL, et al. Comparative effectiveness of digital versus film-screen mammography in community practice in the United States: a cohort study. Ann Intern Med. 2011;155:493-502.

43. Randolph WM, Goodwin JS, Mahnken JD, Freeman JL. Regular mammography use is associated with elimination of age-related disparities in size and stage of breast cancer at diagnosis. Ann Intern Med. 2002;137:783-90.

44. Walter LC. What is the right cancer screening rate for older adults. Arch Intern Med. 2011;171:2037-9.

45. Schonberg MA, McCarthy EP, York M, Davis RB, Marcantonio ER. Factors influencing elderly women's mammography screening decisions: implications for counseling. BMC Geriatr. 2007;7:26.

46. Schonberg MA, Walter LC. Talking about stopping cancer screening-not so easy. JAMA Intern Med. 2013;173:532-3.

47. Scinto JD, Gill TM, Grady JN, Holmboe ES. Screening mammography: Is it suitably targeted to older women who are most likely to benefit? J Am Geriatr Soc. 2001;49:1101-4.
48. Lee SJ, Boscardin WJ, Stijacic-Cenzer I, Conell-Price J, O'Brien S, Walter LC. Time lag to benefit after screening for breast and colorectal cancer: meta-analysis of survival data from the United States, Sweden, United Kingdom, and Denmark. BMJ. 2012;346, e8441.

49. Schonberg MA, Hamel MB, Davis RB, et al. Development and Evaluation of a Decision Aid on Mammography Screening for Women 75 Years and Older. JAMA Intern Med. 2013.

50. Cruz M, Covinsky K, Widera EW, Stijacic-Cenzer I, Lee SJ. Predicting 10-year mortality for older adults. JAMA. 2013;309:874-6.

51. Yourman LC, Lee SJ, Schonberg MA, Widera EW, Smith AK. Prognostic indices for older adults: a systematic review. JAMA. 2012;307:182-92.

52. Kramer BS, Elmore JG. Projecting the benefits and harms of mammography using statistical models: proof or proofiness? J Natl Cancer Inst. $2015 ; 107$.

53. Mandelblatt J, Schechter CB, Lawrence W, Yi B, Cullen J. The SPECTRUM population model of the impact of screening and treatment on U.S. breast cancer trends from 1975 to 2000: principles and practice of the model methods. J Natl Cancer Inst Monogr. 1975;2006:47-55. 